\title{
Synthesis of $n$-Butyl Lactate by Transition-Metal-Substituted Phosphotungstic Acid Salt
}

\author{
Ke $\mathrm{Wu}^{1}, \mathrm{Li} \mathrm{Xu}{ }^{1,2}, \operatorname{Ling} \mathrm{Xu}^{1}$, Lijuan Xie ${ }^{1}$, Zongrui Liu ${ }^{1, ~ *}$ \\ ${ }^{1}$ College of Chemistry and Chemical Engineering, Inner Mongolia University for Nationalities, Tongliao, China \\ ${ }^{2}$ College of Chemistry, Northeast Normal University, Changchun, China
}

Email address:

liuzr716@163.com (Zongrui Liu)

${ }^{*}$ Corresponding author

\section{To cite this article:}

$\mathrm{Ke} \mathrm{Wu}, \mathrm{Li} \mathrm{Xu}$, Ling Xu, Lijuan Xie, Zongrui Liu. Synthesis of n-Butyl Lactate by Transition-Metal-Substituted Phosphotungstic Acid Salt. Science Journal of Chemistry. Vol. 6, No. 4, 2018, pp. 43-49. doi: 10.11648/j.sjc.20180604.12

Received: August 16, 2018; Accepted: September 13, 2018; Published: October 18, 2018

\begin{abstract}
Fatty acid ester perfume occupied an important position in food industry. The characteristics of them were variety, easy synthesis and low price. They were widely used in daily flavor, edible flavor and industrial flavor. POMs were a kind of stong acid bifunctional mild environment-friendly catalysts, their drawback was excellent solubility and could not be reused. Here, series of transition-metal-substituted phosphotungstate $\mathrm{K}_{6}\left[\mathrm{PW}_{11} \mathrm{O}_{39} \mathrm{M}^{\mathrm{II}}\left(\mathrm{H}_{2} \mathrm{O}\right)\right](\mathrm{M}=\mathrm{Cu}, \mathrm{Co}, \mathrm{Ni})$ Lewis acid heterogeneous phase catalysts based on mono-lacunary-Keggin type $\mathrm{K}_{7}\left[\mathrm{PW}_{11} \mathrm{O}_{39}\right]$ were prepared by stereoselect-eve method, $\mathrm{K}_{6}\left[\mathrm{PW}_{11} \mathrm{O}_{39} \mathrm{M}^{\text {II }}\right.$ $\left.\left(\mathrm{H}_{2} \mathrm{O}\right)\right](\mathrm{M}=\mathrm{Cu}, \mathrm{Co}, \mathrm{Ni})$ were abbreviated as $\mathrm{PW}_{11} \mathrm{M}^{\mathrm{II}}\left(\mathrm{H}_{2} \mathrm{O}\right)(\mathrm{M}=\mathrm{Cu}, \mathrm{Co}, \mathrm{Ni})$. They were characterized by FT-IR, PXRD and element analysis. The coordinating water of transition metal was Lewis acid catalytic sites after activated. When mole ratio of butanol and lactic acid was 2: 1, amount of $\mathrm{PW}_{11} \mathrm{M}^{\mathrm{II}}\left(\mathrm{H}_{2} \mathrm{O}\right)(\mathrm{M}=\mathrm{Cu}, \mathrm{Co}, \mathrm{Ni})$ was $0.125 \mathrm{~g}$, volume of cyclohexane was $15 \mathrm{~mL}$, the reaction temperature was $105^{\circ} \mathrm{C}$, reaction time was $2 \mathrm{~h}$, conversion rate of n-butyl lactate were in order: $85.9 \%, 79.6 \%, 66.3 \%$. Activity of $\mathrm{PW}_{11} \mathrm{X}(\mathrm{X}=\mathrm{Cu}, \mathrm{Co}, \mathrm{Ni})$ had no obvious changes after three times recycling. In addition, magnetic studies indicate that antiferromagnetic interactions exist in the three compounds.
\end{abstract}

Keywords: Transition-Metal-Substituted, Substituted Phosphotungstic Acid Salt, n-Butyl Lactate, Lewis Acid Catalysis

\section{Introduction}

Synthetic perfume especially ester synthetic perfume are the important materials for food industry, cosmetics and drugs manufacture industry. Strong inorganic acid such as $\mathrm{H}_{2} \mathrm{SO}_{4}$ is the classical acid catalyst for the industrial progress of synthesis of synthetic ester perfume. [1-3] As we all know, the shortage of process route are equipment corrosion serious, poor selectivity and complicated process. $[4,5]$ With the enhancement of awareness of environment protection, scientist are working on small corrosion performance, low price, high performance catalyst. [6-9]

Polyoxometalates (POMs), as a class of nanosized metaloxo clusters composed of group VI (Mo and $\mathrm{W}$ ) and group V $(\mathrm{V}, \mathrm{Nb}$ and $\mathrm{Ta}$ ) elements in their highest oxidation state, have received increasing attention owing to their aesthetically appealing structures and wide applications such as in the fields of magnetism, [10-12] catalysis, [13-20] and proton conduction. [22-24] Due to their strong acidity and fast multielectron transformation activity, POMs can be employed as acid, redox and bifunctional (acid and redox) catalyst for organic reactions. As homogeneous catalyst, POMs possess high activity, good selectivity and mild operation conditions. But there are still some difficulties for solve the problem of separation and recycling of POMs catalyst.

Inspired by the properties of POMs, series heterogeneous catalyst $\mathrm{PW}_{11} \mathrm{M}^{\mathrm{II}}\left(\mathrm{H}_{2} \mathrm{O}\right)(\mathrm{M}=\mathrm{Cu}, \mathrm{Co}, \mathrm{Ni})$ were explored by introducing transition metal $(\mathrm{M}=\mathrm{Cu}, \mathrm{Co}, \mathrm{Ni})$ into mono-lacunary-Keggin type $\mathrm{K}_{7}\left[\mathrm{PW}_{11} \mathrm{O}_{39}\right]$. When low-valent transition metal ions such as $\mathrm{Cu}^{2+}, \mathrm{Co}^{2+}, \mathrm{Ni}^{2+}$ replace tungsten atom form substituted saturated POMs, these low-valence metal ions usually coordinated with one or more coordination water molecules. After a simple heating and activation, the coordination water lost and $\mathrm{M}^{2+}$ become the Lewis acid catalytic center. The Lewis acid catalytic performance of $\mathrm{PW}_{11} \mathrm{M}^{\mathrm{II}}\left(\mathrm{H}_{2} \mathrm{O}\right)(\mathrm{M}=\mathrm{Cu}, \mathrm{Co}, \mathrm{Ni})$ has been investigated by their catalytic conversion rates for synthesis of n-butyl lactate. 


\section{Experiment}

\subsection{Materials and Methods}

$\mathrm{K}_{7}\left[\mathrm{PW}_{11} \mathrm{O}_{39}\right]$ was prepared according to the literature procedures. [25] Other chemicals were obtained commercially and used without further purification. Fourier transform infrared (FT-IR) spectra of skeletal vibration of materials were recorded using KBr flake on a SHIMADZU NICOLET AVATAR 370 DTGS spectrometer. Powder X-ray diffraction (PXRD) patterns were recorded on a Shimadzu XRD-6000 diffractometer system equipped with $\mathrm{Ni}$-filtered $\mathrm{Cu}$ target $\mathrm{K} \alpha$-ray (operation at $40 \mathrm{kV}, 40 \mathrm{~mA}$, wavelength $\lambda=0.15418$ $\mathrm{nm})$. Diffractions were carried out in the ranges $(2 \theta)$ of $5^{\circ}$ to $80^{\circ}$ at the scanning speed of $0.02^{\circ} / \mathrm{min}$. The magnetic susceptibility data were obtained on a SQUID magnetometer (Quantum Design, MPMS-5) in the temperature range 2-300 $\mathrm{K}$ with applied field of $1000 \mathrm{Oe}$. GC analyses were performed on an Agilent 6820 instrument with a flame ionization detector. Elemental analyses for $\mathrm{C}, \mathrm{N}$, and $\mathrm{H}$ were performed on a Perkin-Elmer $2400 \mathrm{CHN}$ elemental analyzer, and for $\mathrm{Cu}, \mathrm{Co}$, $\mathrm{Ni}, \mathrm{P}, \mathrm{W}$ were determined with a PLASMASPEC (I) ICP atomic emission spectrometer.

\subsection{Preparation of $P W_{11} X(X=C u, C o, N i)$}

$\mathrm{K}_{6}\left[\mathrm{PW}_{11} \mathrm{O}_{39} \mathrm{M}^{\mathrm{II}}\left(\mathrm{H}_{2} \mathrm{O}\right)\right](\mathrm{M}=\mathrm{Cu}, \mathrm{Co}, \mathrm{Ni})$ were prepared according to the literature procedures. [26] Solution A: 6.0 $\mathrm{g} \mathrm{K}_{7}\left[\mathrm{PW}_{11} \mathrm{O}_{39}\right]$ solid samples were dissolved in $18.0 \mathrm{~mL}$ distilled water. Solution B: $0.41 \mathrm{~g} \mathrm{CuSO}_{4} \cdot 5 \mathrm{H}_{2} \mathrm{O}$ were dissolved in $5.0 \mathrm{~mL}$ distilled water, solution $\mathrm{B}$ was heated to $30-40^{\circ} \mathrm{C}$ and slowly poured into solution $\mathrm{A}$, the $\mathrm{pH}$ of mixed solution was adjusted to 5.0 with $1 \mathrm{M} \mathrm{HCl}$ solution. Stirring for $30 \mathrm{~min}$ at $30-40^{\circ} \mathrm{C}$, then mixed solution was cooled to room temperature and $6.0 \mathrm{~g} \mathrm{KCl}$ was added. After stirring for $20 \mathrm{~min}$, the shallow green precipitate $\mathrm{PW}_{11} \mathrm{C}^{\mathrm{II}}\left(\mathrm{H}_{2} \mathrm{O}\right)$ was filtered separation, washed with water and air-dried. Synthetic method of $\mathrm{PW}_{11} \mathrm{Co}^{\text {II }}$ $\left(\mathrm{H}_{2} \mathrm{O}\right)$ and $\mathrm{PW}_{11} \mathrm{Ni}^{\text {II }}\left(\mathrm{H}_{2} \mathrm{O}\right)$ were similar to $\mathrm{PW}_{11} \mathrm{Cu}^{\text {II }}\left(\mathrm{H}_{2} \mathrm{O}\right)$, excepted using $\mathrm{CoSO}_{4} \cdot 7 \mathrm{H}_{2} \mathrm{O}$ and $\mathrm{NiSO}_{4} \cdot 6 \mathrm{H}_{2} \mathrm{O}$ instead of $\mathrm{CuSO}_{4} \cdot 5 \mathrm{H}_{2} \mathrm{O}$.

\subsection{Catalytic Reaction}

The esterification reaction was performed in a three-necked round-bottomed flask with appropriate mass of $\mathrm{PW}_{11}{ }^{\mathrm{II}}\left(\mathrm{H}_{2} \mathrm{O}\right)(\mathrm{M}=\mathrm{Cu}, \mathrm{Co}, \mathrm{Ni})$. Then, reasonable volume ratio of butanol and lactic acid, and cyclohexane water-carrying agent were added with magnetic stirring, the device was equipped with thermometer refluxing condenser tube and water segregator in atmospheric pressure in several hours. The solution was heated to boil and refluxed until no water flowed off. The resultant solution was distilled and purified. Samples should be taken every half an hour, and the sample should be diluted with acetone, the yield of n-butyl lactate can be measured by GC analysis with sample diluted by aceton solution.

\section{Results and Discussion}

\subsection{FT-IR Studies}

The Fourier Transform infrared spectroscopy (FT-IR) of $\mathrm{PW}_{11} \mathrm{M}^{\mathrm{II}}\left(\mathrm{H}_{2} \mathrm{O}\right)(\mathrm{M}=\mathrm{Cu}, \mathrm{Co}, \mathrm{Ni})$ between 4000 and $400 \mathrm{~cm}^{-1}$ with $\mathrm{KBr}$ pellet was showed in Figure 1. In which, the absorption in the region of $1060-510 \mathrm{~cm}^{-1}$ were attributed to characteristic vibration patterns of $\left[\mathrm{PW}_{11} \mathrm{O}_{39}\right]^{7-}$ unit. The absorption at $1060 \mathrm{~cm}^{-1}$ and $950 \mathrm{~cm}^{-1}$ were terminal $\mathrm{W}=\mathrm{O}_{\mathrm{t}}\left(\mathrm{O}_{\mathrm{t}}\right.$ was terminal O) vibrations. The absorption at $900 \mathrm{~cm}^{-1}$ was attributable to the center $\mathrm{W}-\mathrm{O}_{\mathrm{b}}-\mathrm{W}\left(\mathrm{O}_{\mathrm{c}}\right.$ was center $\mathrm{O}$ atom $)$ vibration. The absorption at 809 and $510 \mathrm{~cm}^{-1}$ were bridging $\mathrm{W}-\mathrm{O}_{\mathrm{b}}-\mathrm{W}\left(\mathrm{O}_{\mathrm{b}}\right.$ was bridged $\mathrm{O}$ atom $)$ vibration. The absorption at $1673 \mathrm{~cm}^{-1}$ was the vibrations of P P-O. The characteristic absorption at $3428 \mathrm{~cm}^{-1}$ derived from the $\mathrm{O}-\mathrm{H}$ stretching vibration of $\mathrm{H}_{2} \mathrm{O}$.

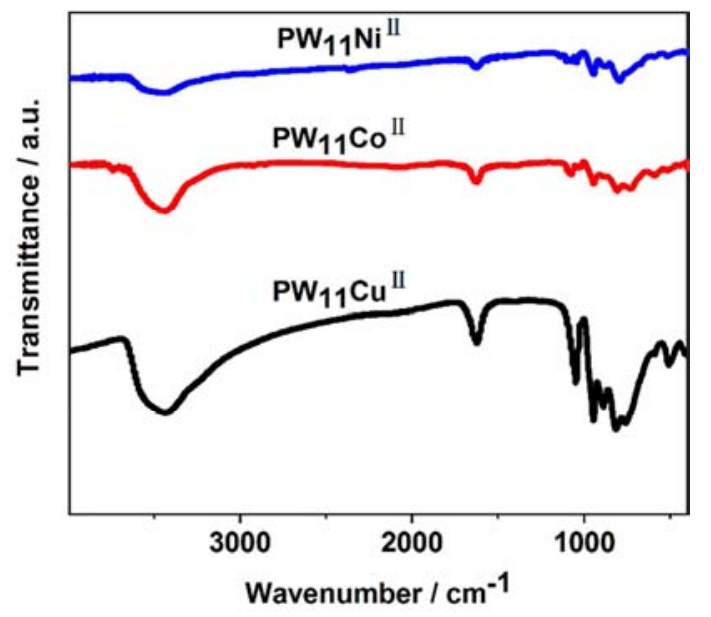

Figure 1. FT-IR patterns of catalysts.

\subsection{XRD Studies}

Figure 2 was PXRD patterns of $\mathrm{PW}_{11} \mathrm{M}^{\mathrm{II}}\left(\mathrm{H}_{2} \mathrm{O}\right)(\mathrm{M}=\mathrm{Cu}$, $\mathrm{Co}, \mathrm{Ni})$ samples. All of those samples have perfectly confirmed with diffraction peaks of Keggin structure, whose $2 \theta$ were $28^{\circ}, 48^{\circ}$ and $58^{\circ}$, which indicated that $\mathrm{PW}_{11} \mathrm{M}^{\mathrm{II}}$ $\left(\mathrm{H}_{2} \mathrm{O}\right)(\mathrm{M}=\mathrm{Cu}, \mathrm{Co}, \mathrm{Ni})$ samples were isomorphic mono-substituted Keggin type POMs.

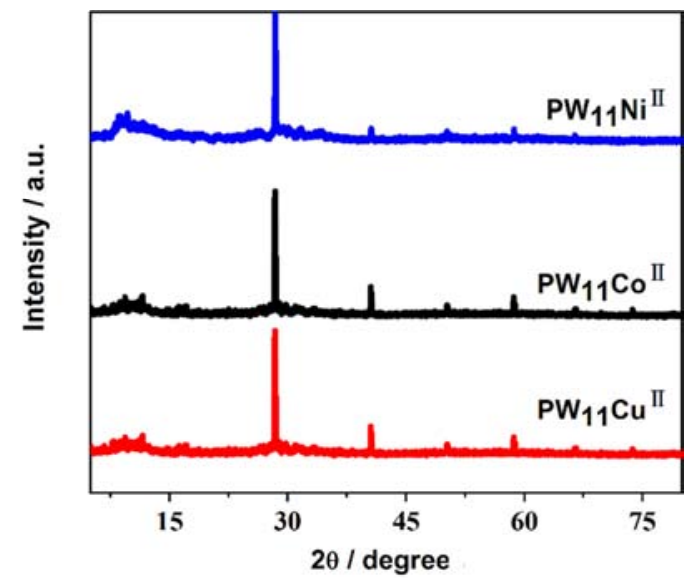

Figure 2. XRD patterns of catalysts. 


\subsection{Element Analysis}

The $\mathrm{PW}_{11} \mathrm{M}^{\mathrm{II}}\left(\mathrm{H}_{2} \mathrm{O}\right)(\mathrm{M}=\mathrm{Cu}, \mathrm{Co}, \mathrm{Ni})$ solid samples were dissolved in $20 \mathrm{~mL}$ concentrated nitric acid $\left(\mathrm{HNO}_{3}\right)$ then was transferred to a Teflon-lined stainless-steel autoclave and sealed. After being heated at $120^{\circ} \mathrm{C}$ for $24 \mathrm{~h}$, it was cooled to room temperature and was transferred to $1 \mathrm{~L}$ volumetric flask diluted into $1 \mu \mathrm{g} / \mathrm{mL}$ solution for elemental analysis. The experimental data were shown in Table 1.

Table 1. Elemental anlysis for $\mathrm{PW}_{11} \mathrm{M}^{I I}\left(\mathrm{H}_{2} \mathrm{O}\right)(\mathrm{M}=\mathrm{Cu}$, Co, $\mathrm{Ni})$.

\begin{tabular}{lll}
\hline Catalyst & Anal. Calcd / \% & Found / \% \\
\hline \multirow{3}{*}{$\mathrm{PW}_{11} \mathrm{Cu}$} & H 0.07; O 21.38; & H 0.08; O 21.39; \\
& K 7.84; P 1.03; & K 7.82; P 1.02; \\
& W 67.56; Cu 2.12. & W 67.58; Cu 2.11. \\
\multirow{2}{*}{$\mathrm{PW}_{11} \mathrm{Co}$} & H 0.07; O 21.41; & H 0.07; O 21.43; \\
& K 7.85; P 1.04; & K 7.84; P 1.03; \\
& W 67.66; Co 1.97. & W 67.67; Co 1.96. \\
& H 0.07; O 21.41; & H 0.06; O 21.40; \\
& K 7.84 P 1.04; & K 7.85; P 1.05; \\
& W 67.67; Ni 1.97. & W 67.65; Co 1.99. \\
\hline
\end{tabular}

(a)

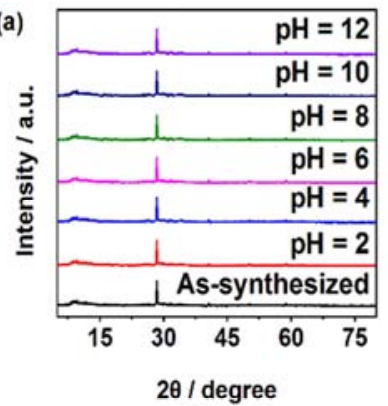

(c)

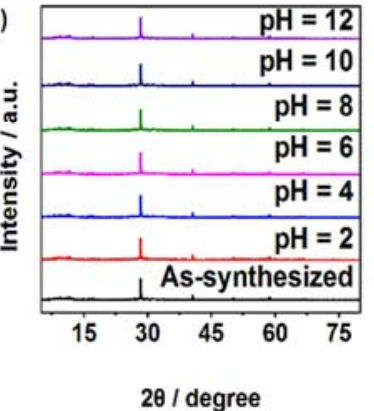

(e)

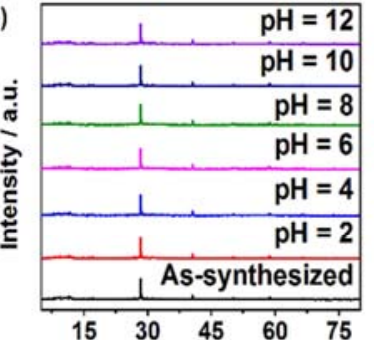

$2 \theta /$ degree

\subsection{Chemical Stability Studies}

In order to further detect chemical stability of $\mathrm{PW}_{11} \mathrm{Cu}^{\mathrm{II}}\left(\mathrm{H}_{2} \mathrm{O}\right), \mathrm{PW}_{11} \mathrm{Co}^{\mathrm{II}}\left(\mathrm{H}_{2} \mathrm{O}\right)$ and $\mathrm{PW}_{11} \mathrm{Ni}^{\mathrm{II}}\left(\mathrm{H}_{2} \mathrm{O}\right), \mathrm{PXRD}$ of the three compounds were tested with different $\mathrm{pH}$ valules(2-12) aqueous solution and different organic reagents. Soaking in the same volume of aqueous solution with $\mathrm{pH}$ range between 2-12 for 24 hours, as shown in Figure 3a, 3c, 3e, the PXRD peaks of the three compounds have no significant changes indicated that the three compounds were stable between the $\mathrm{pH}$ range of 2-12. Then soaking the three compounds in different organic solvent s (acetone, methanol, ethanol, dimdimethylformamide, n-butanol and lactic acid) with same volume after 24 hours then tested their PXRD. As shown in Figure 3b, 3d, 3f, PXRD peaks had no obvious changes compared with as-synthesized sample, which proved that the three compounds were stable in common organic solvents. All of experimental results shown that the three compounds were stable in these organic solvent (Figure 3b). The experimental results showed that the three compounds were chemical stable with strong acid and alkali aqueous solution and typical organic solvents.
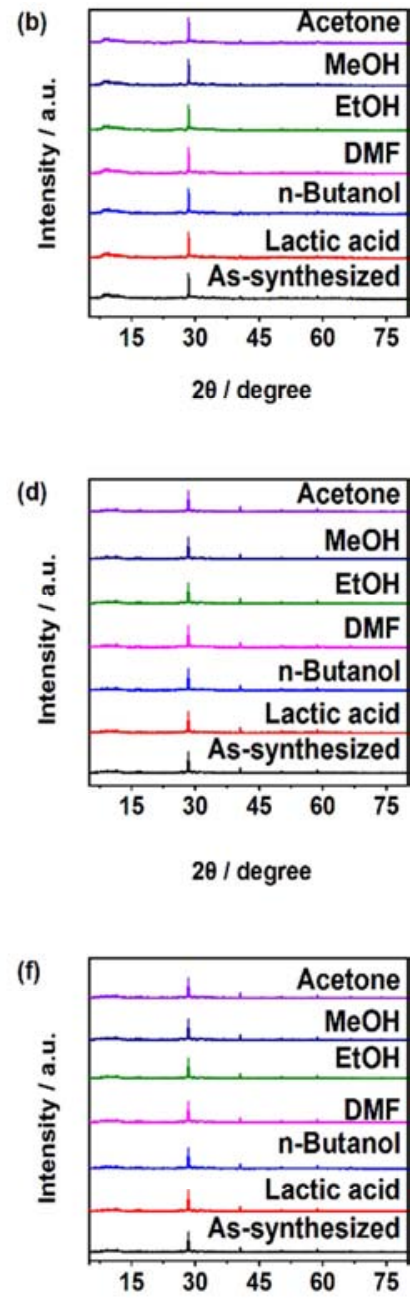

$2 \theta /$ degree

Figure 3. $\mathrm{PXRD}$ patterns of: (a) $\mathrm{P} W_{1 I} \mathrm{Ni}^{\prime \prime}\left(\mathrm{H}_{2} \mathrm{O}\right)$ was disposed with $\mathrm{pH}$ values of aqueous solutions; (b) $\mathrm{P} W_{I I} \mathrm{Ni}^{\prime \prime}\left(\mathrm{H}_{2} \mathrm{O}\right)$ was soaked in different organic solvents; (c) $\mathrm{PW}_{I I} \mathrm{Co}^{\prime \prime}\left(\mathrm{H}_{2} \mathrm{O}\right)$ was disposed with $\mathrm{pH}$ values of aqueous solutions; (d) $\mathrm{PW}_{I I} \mathrm{Co}^{\text {II }}\left(\mathrm{H}_{2} \mathrm{O}\right)$ was soaked in different organic solvents; (e) $\mathrm{PW}_{l l} \mathrm{Cu}$ "I $\left(\mathrm{H}_{2} \mathrm{O}\right)$ was disposed with $\mathrm{pH}$ values of aqueous solutions; (f) $\mathrm{PW} W_{l l} \mathrm{Cu}^{\prime \prime}\left(\mathrm{H}_{2} \mathrm{O}\right)$ was soaked in different organic solvents. 


\subsection{Reaction Results}

\subsubsection{Effect on Esterification Rate at Different Ratio of Lactate Acid and Butyl Alcohol}

When reaction time was $2 \mathrm{~h}$, reaction temperature was $100^{\circ} \mathrm{C}$, amount of $\mathrm{PW}_{11} \mathrm{M}^{\mathrm{II}}\left(\mathrm{H}_{2} \mathrm{O}\right)(\mathrm{M}=\mathrm{Cu}, \mathrm{Co}, \mathrm{Ni})$ was 0.125 $\mathrm{g}$, amount of cyclohexane was $15 \mathrm{~mL}$, molar ratio of butanol and lactic acid were $1.25: 1,1.5: 1,1.75: 1,2: 1,2.25: 1$, the effects of molar ratio of n-butanol and lactic acid on esterification rate showed in Figure 4. The conversion rate of $\mathrm{PW}_{11} \mathrm{Cu}^{\text {II }}\left(\mathrm{H}_{2} \mathrm{O}\right)$ were in order: $47.31 \%, 53.67 \%, 59.39 \%$, $82.92 \%, 82.98 \%$. The conversion rate of $\mathrm{PW}_{11} \mathrm{Co}^{\text {II }}\left(\mathrm{H}_{2} \mathrm{O}\right)$ were in order: $43.25 \%, 48.11 \%, 57.72 \%, 78.76 \%, 78.94 \%$. The conversion rate of $\mathrm{PW}_{11} \mathrm{Ni}^{\mathrm{II}}\left(\mathrm{H}_{2} \mathrm{O}\right)$ were in order: $39.76 \%$, $43.75 \%, 53.19 \%, 64.39 \%, 63.97 \%$. The activity of $\mathrm{PW}_{11} \mathrm{M}^{\text {II }}$ $\left(\mathrm{H}_{2} \mathrm{O}\right)$ were $\mathrm{PW}_{11} \mathrm{Cu}^{\text {II }}\left(\mathrm{H}_{2} \mathrm{O}\right)>\mathrm{PW}_{11} \mathrm{Co}^{\text {III }}\left(\mathrm{H}_{2} \mathrm{O}\right)>\mathrm{PW}_{11} \mathrm{Ni}^{\text {II }}$ $\left(\mathrm{H}_{2} \mathrm{O}\right)$. Conversion rate increases with increase of molar ratio of n-butyl alcohol and lactate acid. When conversion rate reached maximum, conversion rate did not increace with the increase of molar ratio of n-butyl alcohol and lactate acid, which might because effect of mole ratio of reaction equilibrium.

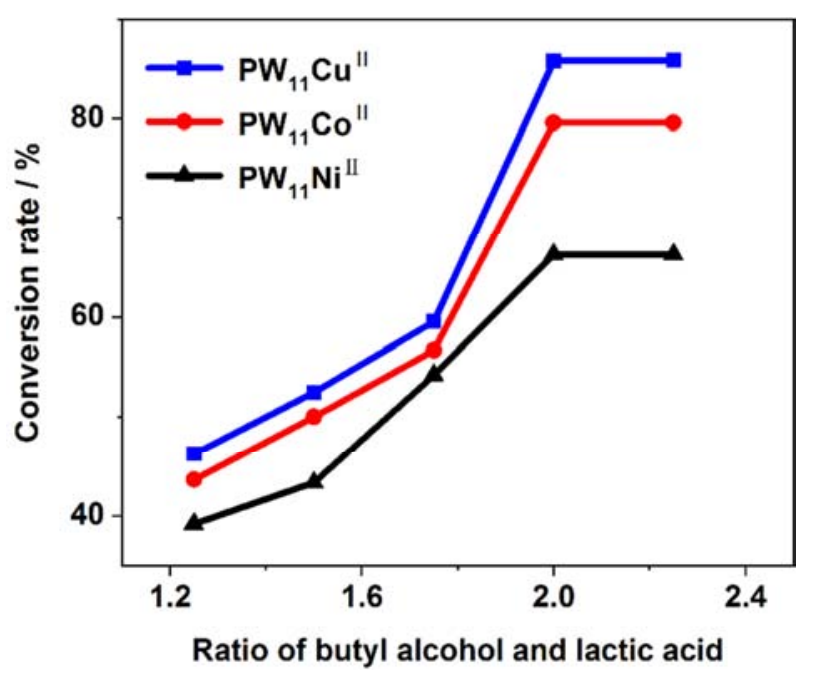

Figure 4. Effect on esterification rate at different ratio of butyl alcohol and lactate acid.

\subsubsection{Effect of Amount of Catalyst on Esterification Rate}

When reaction time was $2 \mathrm{~h}$, reaction temperature was $100^{\circ} \mathrm{C}$, molar ratio of butanol and lactic acid were $2: 1$, volume of cyclohexane was $15 \mathrm{~mL}$, amount of $\mathrm{PW}_{11} \mathrm{M}^{\mathrm{II}}\left(\mathrm{H}_{2} \mathrm{O}\right)$ $(\mathrm{M}=\mathrm{Cu}, \mathrm{Co}, \mathrm{Ni})$ was $0.125 \mathrm{~g}$, effects of amount of $\mathrm{PW}_{11} \mathrm{M}^{\mathrm{II}}$ $\left(\mathrm{H}_{2} \mathrm{O}\right)(\mathrm{M}=\mathrm{Cu}, \mathrm{Co}, \mathrm{Ni})$ on esterification rate shown in Figure 5. Conversion rate increases with increase of amount of $\mathrm{PW}_{11} \mathrm{M}^{\mathrm{II}}\left(\mathrm{H}_{2} \mathrm{O}\right)$. When conversion rate reached maximum, conversion rate did not increace with increase of amount of catalysts, which might because the concentration of catalysts were too dense to reunite in the system lead to no further growth of conversion rate. The conversion rate of $\mathrm{PW}_{11} \mathrm{Cu}^{\text {II }}$ $\left(\mathrm{H}_{2} \mathrm{O}\right)$ were in order: $58.96 \%, 45.73 \%, 81.97 \%, 84.98 \%$, $83.67 \%$. The conversion rate of $\mathrm{PW}_{11} \mathrm{Co}^{\mathrm{II}}\left(\mathrm{H}_{2} \mathrm{O}\right)$ were in order: $49.16 \%, 63.71 \%, 73.86 \%, 77.29 \%, 79.91 \%$. The conversion rate of $\mathrm{PW}_{11} \mathrm{Ni}^{\mathrm{II}}\left(\mathrm{H}_{2} \mathrm{O}\right)$ were in order: $36.36 \%, 53.19 \%$, $57.96 \%, 66.17 \%, 66.03 \%$. The activity of $\mathrm{PW}_{11} \mathrm{M}^{\mathrm{II}}\left(\mathrm{H}_{2} \mathrm{O}\right)$ were $\mathrm{PW}_{11} \mathrm{Cu}^{\text {II }}\left(\mathrm{H}_{2} \mathrm{O}\right)>\mathrm{PW}_{11} \mathrm{Co}^{\text {II }}\left(\mathrm{H}_{2} \mathrm{O}\right)>\mathrm{PW}_{11} \mathrm{Ni}^{1 \mathrm{II}}\left(\mathrm{H}_{2} \mathrm{O}\right)$.

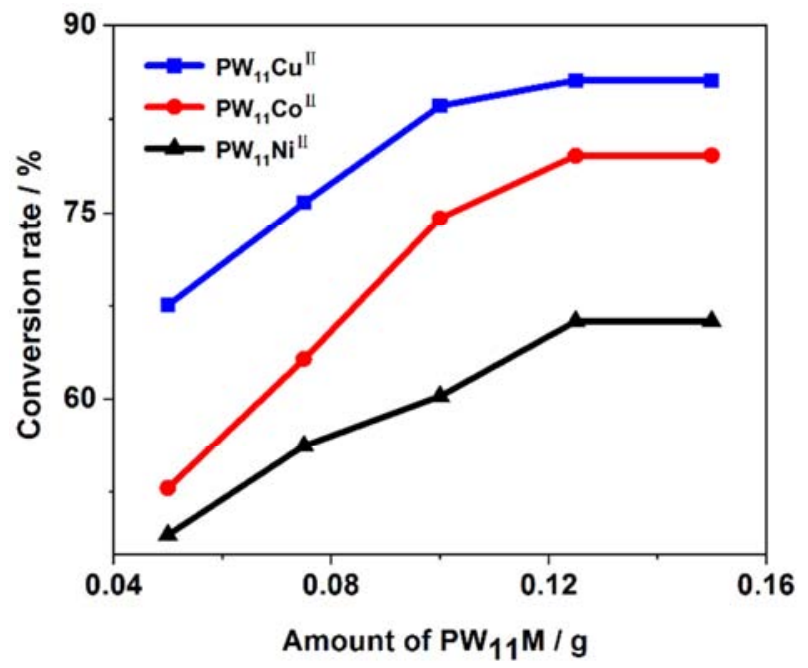

Figure 5. Effect of amount of catalyst on esterification rate.

\subsubsection{Effect of Reaction Time on Estertification Rate}

When reaction temperature was $100^{\circ} \mathrm{C}$, molar ratio of butanol and lactic acid were 2:1, volume of cyclohexane was $15 \mathrm{~mL}$, amount of $\mathrm{PW}_{11} \mathrm{M}^{\mathrm{II}}\left(\mathrm{H}_{2} \mathrm{O}\right)(\mathrm{M}=\mathrm{Cu}, \mathrm{Co}, \mathrm{Ni})$ was 0.125 $\mathrm{g}$, reaction time was $1 \mathrm{~h}, 1.5 \mathrm{~h}, 2 \mathrm{~h}, 2.5 \mathrm{~h}, 3 \mathrm{~h}$; Effects of reaction time on esterification rate showed in Figure 6. Conversion rate increases with increase of reaction time. When conversion rate reached maximum at $2.0 \mathrm{~h}$, conversion rate did not increase with reaction time, which might because reaction equilibrium have been reached at $2 \mathrm{~h}$. The conversion rate of $\mathrm{PW}_{11} \mathrm{Cu}^{\mathrm{II}}\left(\mathrm{H}_{2} \mathrm{O}\right)$ were in order: $58.73 \%$, $73.15 \%, 82.41 \%, 82.37 \%, 82.36 \%$. The conversion rate of $\mathrm{PW}_{11} \mathrm{Co}^{\mathrm{II}}\left(\mathrm{H}_{2} \mathrm{O}\right)$ were in order: $44.92 \%, 53.96 \%, 78.35 \%$, $75.32 \%, 75.29 \%$. The conversion rate of $\mathrm{PW}_{11} \mathrm{Ni}^{\mathrm{II}}\left(\mathrm{H}_{2} \mathrm{O}\right)$ were in order: $31.93 \%, 46.79 \%, 63.99 \%, 64.01 \%, 63.97 \%$. The activity of $\mathrm{PW}_{11} \mathrm{M}^{\text {II }}\left(\mathrm{H}_{2} \mathrm{O}\right)$ were $\mathrm{PW}_{11} \mathrm{Cu}^{\text {II }}\left(\mathrm{H}_{2} \mathrm{O}\right)>\mathrm{PW}_{11} \mathrm{Co}^{\text {II }}$ $\left(\mathrm{H}_{2} \mathrm{O}\right)>\mathrm{PW}_{11} \mathrm{Ni}^{\mathrm{II}}\left(\mathrm{H}_{2} \mathrm{O}\right)$.

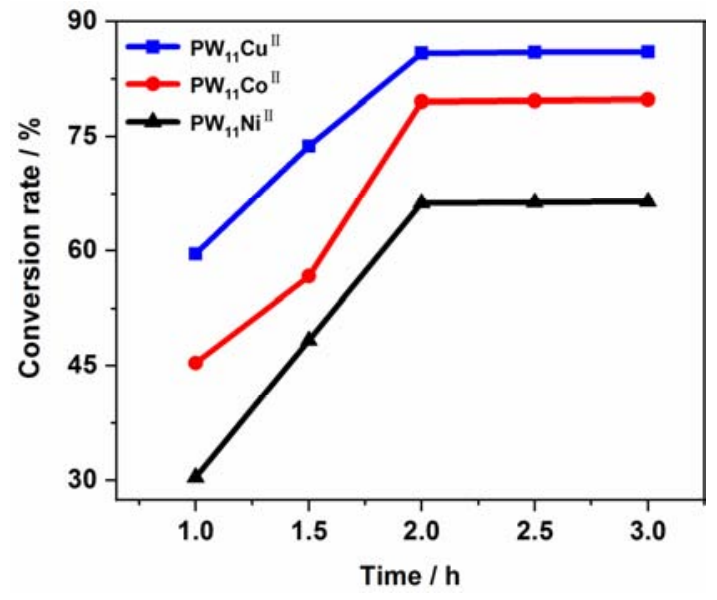

Figure 6. Effect of different reactional time on esterification rate. 


\subsubsection{Effect of Reaction Temperature on Estertification Rate}

When reaction time was $2 \mathrm{~h}$, molar ratio of butanol and lactic acid were $2: 1$, volume of cyclohexane was $15 \mathrm{~mL}$, amount of $\mathrm{PW}_{11} \mathrm{M}^{\mathrm{II}}\left(\mathrm{H}_{2} \mathrm{O}\right)(\mathrm{M}=\mathrm{Cu}, \mathrm{Co}, \mathrm{Ni})$ was $0.125 \mathrm{~g}$, reaction temperature was $90^{\circ} \mathrm{C}, 95^{\circ} \mathrm{C}, 100^{\circ} \mathrm{C}, 105^{\circ} \mathrm{C}, 110^{\circ} \mathrm{C}$, the effects of reaction temperature on esterification rate showed in Figure 7. Conversion rate increases with increase of reaction time. When conversion rate reached maximum at $100^{\circ} \mathrm{C}$, conversion rate did not increase with reaction temperature, which might because reaction equilibrium have been reached at $100^{\circ} \mathrm{C}$. The conversion rate of $\mathrm{PW}_{11} \mathrm{Cu}^{\mathrm{II}}\left(\mathrm{H}_{2} \mathrm{O}\right)$ were in order: $47.92 \%, 61.38 \%, 82.59 \%, 82.53 \%, 82.52 \%$. The conversion rate of $\mathrm{PW}_{11} \mathrm{Co}^{\mathrm{II}}\left(\mathrm{H}_{2} \mathrm{O}\right)$ were in order: $44.16 \%$, $58.46 \%, 78.17 \%, 78.13 \%, 78.11 \%$. The conversion rate of $\mathrm{PW}_{11} \mathrm{Ni}^{\mathrm{II}}\left(\mathrm{H}_{2} \mathrm{O}\right)$ were in order: $36.03 \%, 51.07 \%, 66.18 \%$, $66.16 \%, 66.13 \%$. The activity of $\mathrm{PW}_{11} \mathrm{M}^{\mathrm{II}}\left(\mathrm{H}_{2} \mathrm{O}\right)$ were $\mathrm{PW}_{11} \mathrm{Cu}^{\text {II }}\left(\mathrm{H}_{2} \mathrm{O}\right)>\mathrm{PW}_{11} \mathrm{Co}^{\text {II }}\left(\mathrm{H}_{2} \mathrm{O}\right)>\mathrm{PW}_{11} \mathrm{Ni}^{\text {II }}\left(\mathrm{H}_{2} \mathrm{O}\right)$.

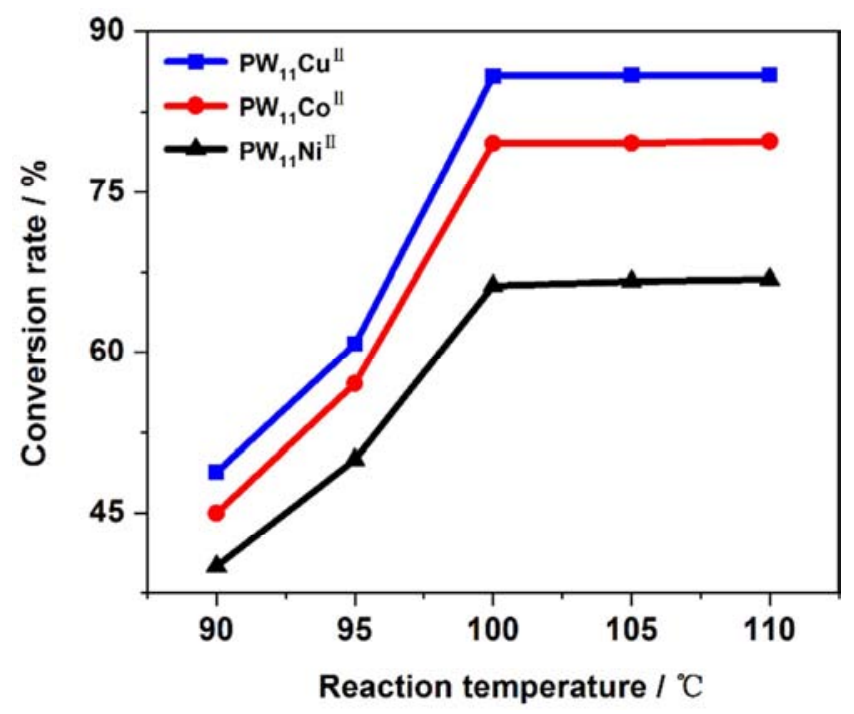

Figure 7. Effect of different temperature on esterification rate.

\subsubsection{Effect of Volume of Cyclohexane on Estertification Rate}

When reaction time was $2 \mathrm{~h}$, molar ratio of butanol and lactic acid were $2: 1$, amount of $\mathrm{PW}_{11} \mathrm{M}^{\mathrm{II}}\left(\mathrm{H}_{2} \mathrm{O}\right)(\mathrm{M}=\mathrm{Cu}, \mathrm{Co}$, $\mathrm{Ni}$ ) was $0.125 \mathrm{~g}$, reaction temperature was $100^{\circ} \mathrm{C}$, volume of cyclohexane was $9 \mathrm{~mL}, 12 \mathrm{~mL}, 15 \mathrm{~mL}, 18 \mathrm{~mL}, 24 \mathrm{~mL}$, effect of volume of cyclohexane on esterification rate showed in Figure 8. Conversion rate increases with increase of reaction time. When conversion rate reached maximum with $15 \mathrm{~mL}$ cyclohexane, conversion rate decrease with the increase of volume of cyclohexane, which might because too much cycl-ohexane might lead to decrease of concentration of catalyst. The conversion rate of $\mathrm{PW}_{11} \mathrm{Cu}^{\mathrm{II}}\left(\mathrm{H}_{2} \mathrm{O}\right)$ were in order: $52.65 \%, 67.46 \%, 82.98 \%, 59.61 \%, 56.37 \%$. The conversion rate of $\mathrm{PW}_{11} \mathrm{Co}^{\mathrm{II}}\left(\mathrm{H}_{2} \mathrm{O}\right)$ were in order: $45.13 \%, 61.39 \%$, $77.95 \%, 57.93 \%, 48.97 \%$. The conversion rate of $\mathrm{PW}_{11} \mathrm{Ni}^{\mathrm{II}}$ $\left(\mathrm{H}_{2} \mathrm{O}\right)$ were in order: $43.43 \%, 57.39 \%, 62.09 \%, 51.93 \%$, $32.87 \%$. The activity of $\mathrm{PW}_{11} \mathrm{M}^{\mathrm{II}}\left(\mathrm{H}_{2} \mathrm{O}\right)$ were $\mathrm{PW}_{11} \mathrm{Cu}^{\mathrm{II}}\left(\mathrm{H}_{2} \mathrm{O}\right)>$ $\mathrm{PW}_{11} \mathrm{Co}^{\mathrm{II}}\left(\mathrm{H}_{2} \mathrm{O}\right)>\mathrm{PW}_{11} \mathrm{Ni}^{\text {II }}\left(\mathrm{H}_{2} \mathrm{O}\right)$.

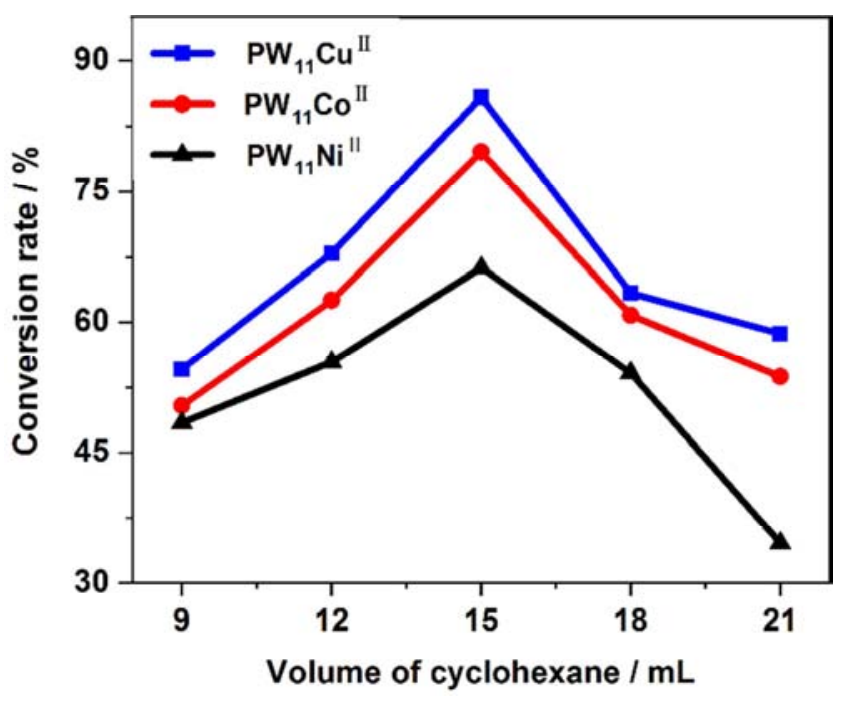

Figure 8. Effect of different volume of cyclohexane on esterification rate.

\subsubsection{Recycling of Catalysts}

The results of recycling test of $\mathrm{PW}_{11} \mathrm{M}^{\mathrm{II}}\left(\mathrm{H}_{2} \mathrm{O}\right)(\mathrm{M}=\mathrm{Cu}, \mathrm{Co}$, $\mathrm{Ni}$ ) were listed in Table 2 . Activity of $\mathrm{PW}_{11} \mathrm{M}(\mathrm{M}=\mathrm{Cu}, \mathrm{Co}, \mathrm{Ni})$ had no obvious changes after three times recycling exhibited that they were stable Lewis acid catalyst.

Table 2. Recycling experiment.

\begin{tabular}{llll}
\hline \multirow{2}{*}{ Catalyst } & Times & & \\
\cline { 2 - 4 } & $\mathbf{1}$ & $\mathbf{2}$ & $\mathbf{3}$ \\
\hline $\mathrm{PW}_{11} \mathrm{Cu}$ & 83.4 & 82.4 & 81.9 \\
$\mathrm{PW}_{11} \mathrm{Co}$ & 79.9 & 79.3 & 78.4 \\
$\mathrm{PW}_{11} \mathrm{Ni}$ & 65.3 & 64.2 & 64.0 \\
\hline
\end{tabular}

\subsubsection{Hot Filtration Experiment}

At the best reaction conditions: reaction time was $2 \mathrm{~h}$, reaction temperature was $100^{\circ} \mathrm{C}$, amount of $\mathrm{PW}_{11} \mathrm{M}^{\mathrm{II}}\left(\mathrm{H}_{2} \mathrm{O}\right)$ $(\mathrm{M}=\mathrm{Cu}, \mathrm{Co}, \mathrm{Ni})$ was $0.125 \mathrm{~g}$, amount of cyclohexane was 15 $\mathrm{mL}$, molar ratio of butanol and lactic acid were 2:1 with hot filteration experiment. After $30 \mathrm{~min}$ of reaction, the catalysts were removed through hot filtration and the filtrate was further heated for $2 \mathrm{~h}$ at $100^{\circ} \mathrm{C}$. As shown in Figure 9, there were no further growth of the conversion indicated that they were heterogeneous catalysts in the catalytic reaction and were not dissolved in the reaction system.

\subsection{Magnetic Property}

The temperature dependence of magnetic susceptibility of $\mathrm{PW}_{11} \mathrm{M}^{\mathrm{II}}\left(\mathrm{H}_{2} \mathrm{O}\right)(\mathrm{M}=\mathrm{Cu}, \mathrm{Co}, \mathrm{Ni})$ was investigated at 2$300 \mathrm{~K}$ in an applied magnetic field of 1000 Oe. Because the molecular structures of the three compounds were very similar, take $\mathrm{PW}_{11} \mathrm{Cu}{ }^{\mathrm{II}}\left(\mathrm{H}_{2} \mathrm{O}\right)$ as an example to introduce their properties. As shown in Figure 10(a), the ${ }_{M}$ versus $T$ plot demonstrated the ${ }_{M}$ value slowly increases from $0.0071 \mathrm{emu} \mathrm{mol}^{-1}$ at $300 \mathrm{~K}$ to $0.087 \mathrm{emu} \mathrm{mol}^{-1}$ at 26 $\mathrm{K}$, and then exponentially reached the maximum value of $0.63 \mathrm{emu} \mathrm{mol}^{-1}$ at $2 \mathrm{~K}$. The ${ }_{\mathrm{M}} \mathrm{T}$ value of 1 is $2.82 \mathrm{emu} \mathrm{K}$ $\mathrm{mol}^{-1}$ at $300 \mathrm{~K}$ (Fig. 4), which is larger than the theoretical value of $1.125 \mathrm{emu} \mathrm{K} \mathrm{mol}{ }^{-1}$ expected from three isolated 
$\mathrm{Cu}^{2+}(\mathrm{S}=0.5, \mathrm{~g}=2.0)$. As the temperature is lowered, the ${ }_{\mathrm{M}}^{\mathrm{T}}$ value decreases slowly up to 0.186 at $50 \mathrm{~K}$ and then sharply falls to a minimum value of $0.0063 \mathrm{emu} \mathrm{K} \mathrm{mol}^{-1}$ at $2 \mathrm{~K}$. The temperature dependences of ${ }_{M}$ and ${ }_{M} T$ versus $\mathrm{T}$ plots for 1 suggest the presence of antiferromagnetic coupling interactions between $\mathrm{Cu}^{2+}$ centers. As shown in
Figure $10(\mathrm{~b})$, the $\mathrm{M}^{-1}$ versus $\mathrm{T}$ plot follows the CurieWeiss law with $\mathrm{C}=2.98 \mathrm{emu} \mathrm{K} \mathrm{mol}{ }^{-1}$ and $=-22.37 \mathrm{~K}$ in the range of $48-300 \mathrm{~K}$, which further demonstrated the presence of antiferromagnetic interactions between $\mathrm{Cu}^{2+}$ ions in $\mathrm{PW}_{11} \mathrm{Cu}^{\text {II }}\left(\mathrm{H}_{2} \mathrm{O}\right)$.
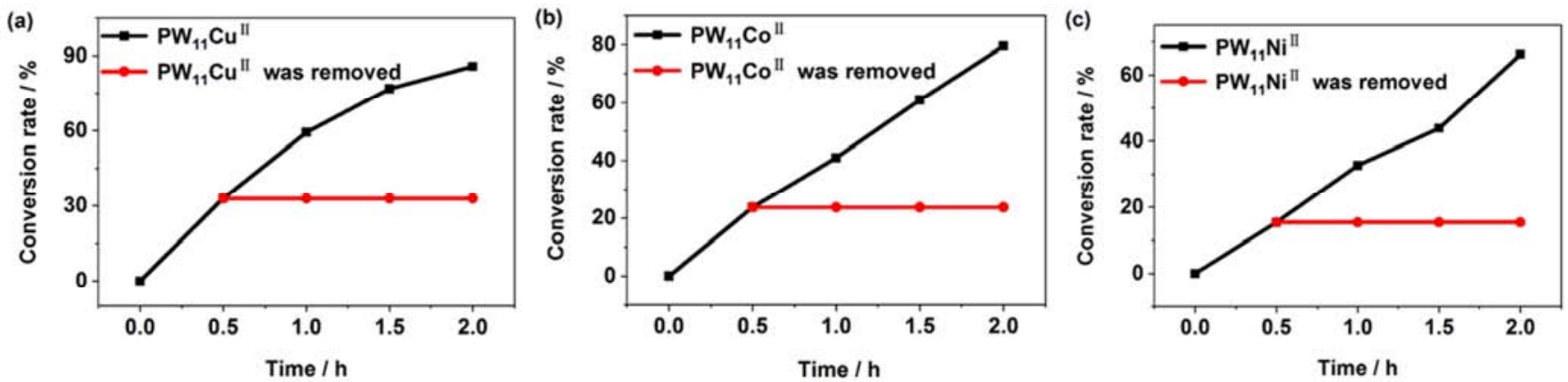

Figure 9. (a) (b) (c) Conversion rete versus time curves with $\mathrm{PW}_{I I} \mathrm{M}^{\prime \prime}\left(\mathrm{H}_{2} \mathrm{O}\right)(\mathrm{M}=\mathrm{Cu}, \mathrm{Co}, \mathrm{Ni})$ as catalyst at $100^{\circ} \mathrm{C}$ and catalyst was removed from the suspension after $30 \mathrm{~min}$.
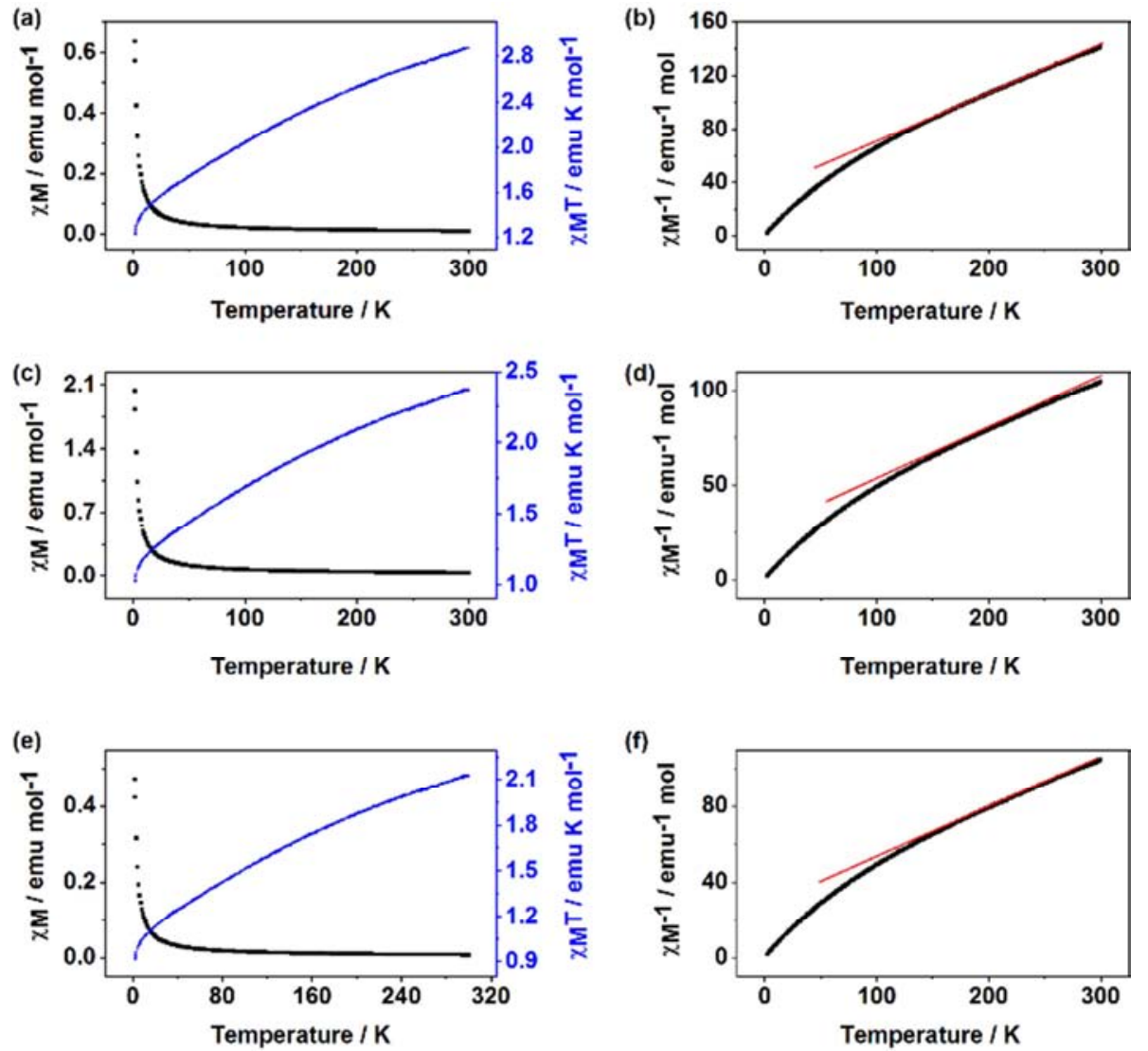

Figure 10. (a) (c) (e) The plots of $\chi_{M}$ and $\chi_{M} T$ vs $T$ in temperature of $2-300 \mathrm{~K}$ for $P W_{l l} M^{\prime \prime}\left(H_{2} O\right)\left(M=C u\right.$, Co, Ni); (b) (d)(f)The plots of $\chi_{M}^{-1} v s$ in temperature of 2-300 K for $\mathrm{PW}_{l l} M^{I I}\left(\mathrm{H}_{2} \mathrm{O}\right)(\mathrm{M}=\mathrm{Cu}$, Co, Ni).

\section{Conclusion}

In summary, series of transition-metal-substituted phosphotungstate $\mathrm{K}_{6}\left[\mathrm{PW}_{11} \mathrm{O}_{39} \mathrm{M}^{\mathrm{II}}\left(\mathrm{H}_{2} \mathrm{O}\right)\right](\mathrm{M}=\mathrm{Cu}, \mathrm{Co}, \mathrm{Ni})$ based on mono-lacunary-Keggin type $\mathrm{K}_{7}\left[\mathrm{PW}_{11} \mathrm{O}_{39}\right]$ were synthetized by stereoselect-eve method. They were chemical stable with strong acid aqueous solution and typical organic solvents. These compounds owned Lewis acid active sites after heating activation. They showed good Lewis acid activities for synthesis of n-butyl lactate, in which, The Lewis acid activity of them were $\mathrm{PW}_{11} \mathrm{Cu}^{\text {II }}\left(\mathrm{H}_{2} \mathrm{O}\right)>\mathrm{PW}_{11} \mathrm{Co}^{\mathrm{II}}\left(\mathrm{H}_{2} \mathrm{O}\right)>$ $\mathrm{PW}_{11} \mathrm{Ni}^{\mathrm{II}}\left(\mathrm{H}_{2} \mathrm{O}\right)$. The catalytic performance was stable after recycling three times. The presence of antiferromagnetic interactions between $\mathrm{Cu}^{2+}, \mathrm{Co}^{2+}$ and $\mathrm{Ni}^{2+}$ ions in $\mathrm{PW}_{11} M^{\mathrm{II}}\left(\mathrm{H}_{2} \mathrm{O}\right)(\mathrm{M}=\mathrm{Cu}, \mathrm{Co}, \mathrm{Ni})$. 


\section{Acknowledgements}

The authors acknowledged the financial support of the National Natural Science Foundation of China (No. 21661026).

\section{References}

[1] L. H. Zhang, Y. W. Tian. 'Synthsis of trimethlolpropane tris-acrylate catalyzed by calcium sulfate whisker. J Mol. Sci., 2009, 25, (6): 375-378

[2] X. W. Kong, Z. J. Li, F. Yan, et al. Synthesis of ethylene glycol monopelargonate with Silica supported sodium bisulfate as catalyst. J Mol. Sci., 2010, 26 (3): 208-212.

[3] D. Y. Chen, J. P. Wang, Y. Bo. Survey of synthesis of lactic esters and its derivatives. Chem. Ind. Eng. Prog., 2002, 21 (4): 243-246.

[4] A. S. H. Kumar, K. T. V. Rao, K. Upendar, et al., Nitration of Methyl 5-Nitrosalicylate Catalyzed by $\mathrm{H}_{6} \mathrm{PMoV}_{3} \mathrm{O}_{40}$ Supported on Silica Gel. Catal. Comm., 2012, 18: 37-40.

[5] S. Mallick, K. M. Parida, Selective Nitration of Phenol over Silicotungstic Acid Supported Zirconia. Catal. Comm., 2007, 8(10): 1487-1492.

[6] S. J. Feng, L. Zhang, Y. H. Ren, et al., Catalytic Hydroxylation of Benzene to Phenol with Hydrogen Peroxide over Cesium Salts of Keggin-type Heteropoly Acids. Acta Chim Sin, 2012, 70(22): 2316-2322.

[7] E. Rafiee, M. Joshaghani, F. Tork, et al., Esterification of Mandelic Acid Catalyzed by Heteropoly Acid. J Mol Catal A: Chem, 2008, 283(1/2): 1-4.

[8] A. Shaabani, M. Behnam, A. H. Rezayan, Tungstophosphoric Acid $\left(\mathrm{H}_{3} \mathrm{PW}_{12} \mathrm{O}_{40}\right)$ Catalyzed Oxidation of Organic Compounds with $\mathrm{NaBrO}$. Catal. Comm, 2009, 10(7): 1074-1078.

[9] M. N. Timofeeva, Acid Catalysis by Heteropoly Acids. Appl. Catal. A, 2003, 256(1/2): 19-35.

[10] X. B. Han, Z. M. Zhang and Zhang T. "Polyoxometalate-based cobalt-phosphate molecular catalysts for visible light-driven water oxidation," J. Am. Chem. Soc., 2014, 136 (14): 5359-5366.

[11] Z. Zhang, Q. Lin, and D. Kurunthu. "Synthesis and photocatalytic properties of a new heteropolyoxoniobate compound: $\left.\mathrm{K}_{10}\left[\mathrm{Nb}_{2} \mathrm{O}_{2}\left(\mathrm{H}_{2} \mathrm{O}\right)_{2}\right]\left[\mathrm{SiNb}_{12} \mathrm{O}_{40}\right]\right\} \cdot 12 \mathrm{H}_{2} \mathrm{O}$," J. Am. Chem. Soc., 2011, 133(18): 6934-6937.

[12] B. Schwarz, J. Forster and M. K Goetz. "Visible-light-driven water oxidation by a molecular manganese vanadium oxide cluster," Angew. Chem. Int. Ed., 2016, 55 (21): 6329-6333.

[13] X. B. Han, Li Y G, and Z. M. Zhang. "Polyoxometalate-based nickel clusters as visible light-driven water oxidation catalysts," J. Am. Chem. Soc., 2015, 137 (16): 5486-5493.
[14] M. Raula, G. G. Or and M. Saganovichl. "Polyoxometalate complexes of anatase-titanium dioxide cores in water," Angew. Chem. Int. Ed., 2015, 54 (42): 12416-12421.

[15] L. Yu, X. Du and Y. Ding. "Efficient visible light-driven water oxidation catalyzed by an all-inorganic copper-containing polyoxometalate," Chem. Comm., 2015, 51 (98): 17443-17446.

[16] K. Suzuki, M. Sugawa and Y. Kikukawa. "Strategic Design and Refinement of Lewis Acid-Base Catalysis by Rare-Earth-Metal-Containing Polyoxometalates," Inorg. Chem., 2012, 51(12): 6953-6961.

[17] K. Kamata, T. Yamaura and Mizuno N. "Chemo- and Regioselective Direct Hydroxylation of Arenes with Hydrogen Peroxide Catalyzed by a Divanadium-Substituted Phosphotungstate," Angew. Chem. Int. Ed., 2012, 51(29): 7275-7278.

[18] Ishimoto R., Kamata K. and N. Mizuno. "A Highly Active Protonated Tetranuclear Peroxotungstate for Oxidation with Hydrogen Peroxide,” Angew. Chem. Int. Ed., 2012, 51(19): $4662-4665$.

[19] Y. Kikukawa, Y. Kuroda and K. Yamaguchi. "Diamond-Shaped $\left[\mathrm{Ag}_{4}\right]^{4+}$ Cluster Encapsulated by Silicotungstate Ligands: Synthesis and Catalysis of Hydrolytic Oxidation of Silanes," Angew. Chem. Int. Ed., 2011, 51(10): 2434-2437.

[20] L. Xu, Y. Lu and L. P. Huang. "Synthesis and Properties of a POMs-based Trinuclear Copper(II) Triazole Framework," RSC Adv. 2018, 8(4), 2034-2041.

[21] J. Li, X. L. Cao and Y. Y. Wang. "The Enhancement on Proton Conductivity of Stable Polyoxometalate-Based Coordination Polymers by the Synergistic Effect of MultiProton Units," Chem-A Eur. J., 2016, 22(27): 9299-9304.

[22] X. Y. Lai, Y. W. Liu and G. C. Yang. "Controllable proton-conducting pathways via situating polyoxometalates in targeting pores of a metal-organic framework," J. Mat. Chem. A, 2017, 5(20): 9611-9617.

[23] E. L. Zhou, C. Qin and X. L. Wang. "Steam-Assisted Synthesis of an Extra-Stable Polyoxometalate-Encapsulating Metal Azolate Framework: Applications in Reagent Purification and Proton Conduction," Chem-A Eur. J., 2015, 21(37): 13058-13064.

[24] M. L. Wei, X. Wang and X. Duan. "Crystal Structures and Proton Conductivities of a MOF and Two POM-MOF Composites Based on $\mathrm{Cu}$ (II) Ions and 2,2'-Bipyridyl-3,3'-dicarboxylic Acid,” Chem-A Eur. J., 2013, 19(5): 1607-1616.

[25] N. Haraguchi, Y. Okaue and T. Isobe. "Stabilization of Tetravalent Cerium upon Coordination of Unsaturated Heteropoly tungstate Anions," Inorg. Chem., 1994, 33(6): 1015-1020.

[26] Q. J. Shan. Synthesis of n-butyl acetate by transition metal mono-substituted tungsphosphoric heteropoly acid catalyst $[\mathrm{J}]$. Chemical industry times, 2013, 27(7). 31-33. 